\title{
Penerapan Metode Certainty Factor Dan Nä̈ve Bayes Untuk Mendiagnosa Penyakit Akibat Gigitan Nyamuk
}

\author{
Yudo Bismo Utomo ${ }^{1}$, Giofani Widya Harsanto ${ }^{2}$ \\ ${ }^{1}$ Teknik Komputer, Fakultas Teknik, Universitas Islam Kadiri Kediri \\ ${ }^{2}$ Teknik Elektro, Fakultas Teknik, Universitas Islam Kadiri Kediri \\ E-mail: ${ }_{1}^{1}$ yudobismo@uniska-kediri.ac.id, ${ }^{2}$ giofaniwidya76@gmail.com
}

\begin{abstract}
Abstrak - Kesehatan merupakan point utama bagi kehidupan umat manusia yang mahal harganya. Akan tetapi banyak dari stakeholder yang mengabaikan kesehatannya yang pada akhirnya penyakit yang dideritanya terlambat untuk didiagnosa, sehingga mencapai tahap kronis yang membuatnya susah untuk diobati. Sama dengan halnya kasus gigitan nyamuk, buruknya perilaku para stakeholder terhadap kebiasaan hidup sehat, seperti membuang sampah sembarangan di selokan rumah dan juga selokannya yang jarang dibersihkan yang membuat drainase selokan rumah tersebut menjadi kurang lancar. Faktor tersebut yang menyebabkan nyamuk membentuk koloni dengan membuat sarangnya, sehingga nyamuk dapat berkembangbiak dengan cepat. Gejala awal yang sering timbul dari gigitan nyamuk demam berdarah, malaria maupun chikungunya pada umumnya sama dan sulit untuk dibedakan. Untuk mengatasi masalah tersebut diatas, perlu dibangun sebuah sistem dimana sistem tersebut dapat membantu stakeholder untuk mendiagnosa penyakit yang disebabkan oleh gigitan nyamuk berbasis android. Metode penelitian yang digunakan dalam penelitian ini adalah metode Research and Development, dikarenakan hasil akhir dari penelitian ini adalah menghasilkan sebuah produk berupa software aplikasi sistem pakar untuk mendiagnosa penyakit akibat gigitan nyamuk berbasis andorid. Hasil yang diperoleh dalam penelitian ini adalah dengan menerapkan metode certainty factor pada aplikasi sistem pakar ini mampu memberikan hasil perhitungan persentase dalam mendeteksi penyakit yang disebabkan oleh gigitan nyamuk, sedangkan metode nä̈ve bayes mampu mendeteksi jenis nyamuk. Hasil akurasi aplikasi sistem pakar yang sudah dibuat dengan menggunakan metode certainty factor dan nä̈ve bayes ini sebesar 90\% dalam mendiagnosa penyakit yang diakibatkan oleh gigitan nyamuk.
\end{abstract}

Kata Kunci - Certainty Factor, Nä̈ve Bayes, Sistem Pakar, Gigitan Nyamuk dan Android.

\begin{abstract}
Health is the main point for the expensive human life. However, many stakeholders ignore their health, which in the end the disease they suffer is too late to be diagnosed, thus reaching a chronic stage that makes it difficult to treat. Similar to the case of mosquito bites, the bad behavior of stakeholders towards healthy living habits, such as littering in the sewers of the house and also the gutters that are rarely cleaned which makes the drainage drainage of the house becomes less smooth. These factors cause mosquitoes to form colonies by making their nests, so mosquitoes can breed quickly. The initial symptoms that often arise from the bite of a dengue mosquito, malaria and chikungunya are generally the same and difficult to distinguish. To overcome the problems mentioned above, it is necessary to build a system where the system can help stakeholders to diagnose diseases caused based mosquito bites by android. The research method used in this research is the Research and Development method, because the final result of this research is to produce a product in the form of an expert system application software to diagnose diseases caused based mosquito bites by andorid. The results obtained in this study are by applying the certainty factor method in the application of this expert system which is able to provide a calculation result in the form of a percentage of confidence in detecting diseases caused by mosquito bites, while the naïve bayes method is able to detect the type of mosquito. The accuracy of the expert system application that has been made using the certainty factor and naïve bayes method is $90 \%$ in diagnosing diseases caused by mosquito bites.
\end{abstract}

Keywords - Certainty Factor, Nä̈ve Bayes, Expert System, Mosquito Bites and Android. 


\section{PENDAHULUAN}

Kesehatan merupakan point utama bagi kehidupan umat manusia yang mahal harganya.[1] Akan tetapi, ada juga perilaku dari stakeholder yang mengabaikan kesehatannya dalam hal kebiasaan hidup sehat, yang pada akhirnya penyakit yang dideritanya terlambat untuk didiagnosa, sehingga mencapai tahap kronis yang membuatnya susah untuk diobati. Padahal pada umumnya, setiap penyakit selalu menunjukan gejala awal yang telah diderita oleh stakeholder.

Sama dengan halnya kasus gigitan nyamuk, buruknya perilaku stakeholder terhadap kebiasaan hidup sehat, seperti membuang sampah sembarangan di selokan rumah dan juga selokannya yang jarang dibersihkan yang membuat drainase selokan rumah tersebut menjadi kurang lancar. Faktor tersebut yang menyebabkan nyamuk membentuk koloni dengan membuat sarangnya, sehingga nyamuk dapat berkembangbiak dengan cepat.[2,3] Gejala awal yang sering timbul dari gigitan nyamuk demam berdarah, malaria maupun chikungunya pada umumnya sama dan sulit untuk dibedakan, diantaranya pusing dan nyeri, demam tinggi secara mendadak, nafsu makan menurun, lemah, letih dan lesu.

Jika hal tersebut diatas tidak segera diatasi, maka kondisi seperti yang diuraikan diatas yang dapat menimbulkan berbagai macam penyakit dari gigitan nyamuk yang dapat meresahkan para stakeholder dan lebih parahnya lagi dapat menyebabkan kematian apabila telat dalam penanganannya.

Untuk mengatasi masalah tersebut diatas, perlu dibangun sebuah sistem dimana sistem tersebut dapat membantu stakeholder untuk mendiagnosa penyakit yang disebabkan oleh gigitan nyamuk. Sistem tersebut bernama sistem pakar. Sistem pakar adalah salah satu bidang kecerdasan buatan yang mengadopsi pengetahuan dari seorang pakar untuk menyelesaikan masalah yang tidak dapat diselesaikan oleh orang awam.[4,5] Jadi, sistem pakar dalam penelitian ini dibuat bukanlah untuk menggantikan fungsi dari seorang dokter, akan tetapi sebagai media atau alat bantu untuk konsultasi yang dapat mendiagnosa suatu penyakit dengan beberapa pertanyaan, kemudian hasil output-nya berupa solusi cara penanggulangannya.

Tujuan yang ingin dicapai dari penelitian ini adalah untuk merancang aplikasi sistem pakar berbasis android yang mampu membantu stakeholder dalam mendiangnosa penyakit yang disebabkan oleh gigitan nyamuk. Adapun manfaat yang diharapkan dari penelitian ini adalah supaya memberikan informasi yang cepat dan akurat kepada stakeholder untuk mendiagnosa jenis penyakit yang disebabkan oleh gigitan nyamuk dan solusi penanganannya

Berdasarkan deskripsi diatas, maka penulis melakukan penelitian tentang "Penerapan Metode Certainty Factor dan Nä̈ve Bayes Untuk Mendiagnosa Penyakit Akibat Gigitan Nyamuk", sehingga dengan adanya aplikasi sistem pakar ini diharapkan dapat membantu stakeholder untuk mendiagnosa penyakit yang disebabkan oleh nyamuk dapat terdeteksi lebih dini.

Suatu metode untuk membuktikan ketidakpastian pemikiran dari seorang pakar, dimana untuk mengakomodasi hal tersebut seorang pakar biasanya menggunakan certainty factor untuk menggambarkan tingkat keyakinan pakar terhadap masalah yang sedang dihadapi, merupakan pengertian dari metode certainty factor.[6] Output dari metode certainty factor ini menghasilkan perhitungan persentase dalam mendeteksi penyakit yang disebabkan oleh gigitan nyamuk, sehingga cocok untuk hasil program yang dibutuhkan dalam penelitian ini.

Adapun pengertian dari metode nä̈ve bayes adalah sebuah teori kondisi probabilitas yang memperhitungkan probabilitas suatu kejadian (hipotesis) yang bergantung pada bukti dari kejadian sebelumnya.[7] Jadi, pada intinya metode naïve bayes digunakan untuk menghitung sekaligus memprediksi probabilitas dari keanggotaan suatu class, sehingga metode ini sangat cocok untuk diterapkan dalam penelitian ini untuk mendeteksi jenis nyamuk.

\section{METODE PENELITIAN}

Penelitian ini menggunakan metode penelitian Research and Development (metode penelitian dan pengembangan atau R\&D). Pengertian dari metode penelitian dan pengembangan ini adalah metode penelitian yang digunakan untuk menghasilkan produk tertentu dan menguji keefektifan dari produk tersebut.[8] Metode ini sangat cocok diterapkan dalam penelitian ini dikarenakan hasil akhir dari penelitian ini adalah menghasilkan sebuah produk berupa software aplikasi sistem pakar untuk mendiagnosa penyakit akibat gigitan nyamuk berbasis andorid.

Langkah-langkah dari penelitian dan pengembangan pada penelitian ini dapat dilihat pada gambar 1 berikut ini. 


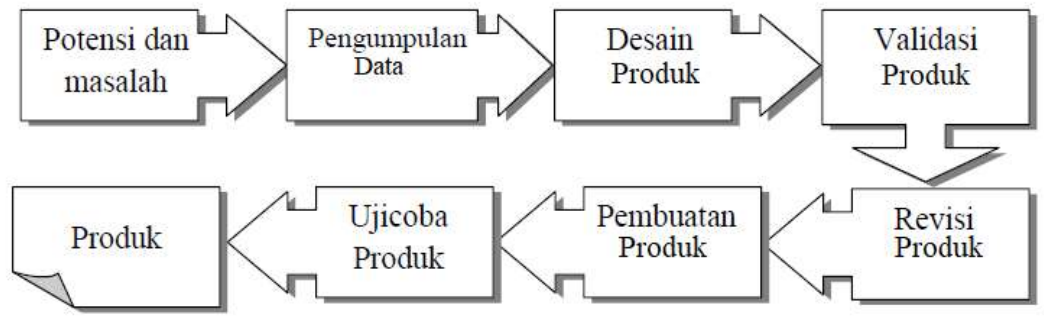

Gambar 1. Alur Penelitian Research and Development [9]

\subsection{Potensi dan Masalah}

Potensi masalah yang diangkat dalam penelitian ini adalah belum adanya aplikasi software yang berbasis android untuk mendiagnosa penyakit akibat gigitan nyamuk. Pakar ahli kesehatan mengatakan bahwa gejala awal yang timbul dari gigitan nyamuk demam berdarah, malaria maupun chikungunya pada umumnya sama dan sulit untuk dibedakan. Jika terlambat untuk didiagnosa dan sampai dalam tahap kronis, maka membuatnya sulit untuk diobati dan bahkan dapat menyebabkan kematian.

\subsection{Pengumpulan Data}

Data yang digunakan pada penelitian ini berupa data gejala penyakit dan nilai CF dari masing-masing gejala serta jenis nyamuk. Data tersebut berasal dari hasil wawancara yang sudah dilakukan oleh peneliti kepada pakar kesehatan yaitu dokter umum, berdasarkan pengetahuan dan pengalaman dokter tersebut dalam menangani pasien. Data yang telah terkumpul dari hasil wawancara disajikan pada tabel 1 berikut ini.

Tabel 1. Data Gejala Penyakit, Nilai CF dan Jenis Nyamuk

\begin{tabular}{|c|l|c|c|c|c|}
\hline \multirow{2}{*}{ Kode } & \multicolumn{1}{|c|}{ Gejala Penyakit } & $\begin{array}{c}\text { Nilai } \\
\text { CF }\end{array}$ & $\begin{array}{c}\text { Demam } \\
\text { Berdarah } \\
\text { (N01) }\end{array}$ & $\begin{array}{c}\text { Malaria } \\
\text { (N02) }\end{array}$ & $\begin{array}{c}\text { Chikungunya } \\
\text { (N03) }\end{array}$ \\
\hline G01 & $\begin{array}{l}\text { Pendarahan diantaranya } \\
\text { mimisan, muntah darah dan } \\
\end{array}$ & 0.8 & $\checkmark$ & - & - \\
\hline BAB berdarah. & $\begin{array}{l}\text { Demam tinggi secara } \\
\text { mendadak, kemudian demam } \\
\text { turun, lalu demam naik lagi. }\end{array}$ & 0.4 & $\checkmark$ & $\checkmark$ & - \\
\hline G03 & Nafsu makan menurun. & 0.3 & $\checkmark$ & $\checkmark$ & - \\
\hline G04 & $\begin{array}{l}\text { Pusing yang diikuti dengan } \\
\text { rasa lemah, letih dan lesu. }\end{array}$ & 0.5 & $\checkmark$ & - & $\checkmark$ \\
\hline G05 & Tubuh terasa dingin. & 0.7 & $\checkmark$ & - & - \\
\hline G06 & $\begin{array}{l}\text { Muncul bintik merah pada } \\
\text { kulit. }\end{array}$ & 0.9 & $\checkmark$ & - & - \\
\hline G07 & Mual disertai dengan muntah. & 0.8 & - & $\checkmark$ & - \\
\hline G08 & Nyeri pada badan. & 0,9 & - & - & $\checkmark$ \\
\hline G09 & Susah buang air besar. & 0.6 & - & - & $\checkmark$ \\
\hline
\end{tabular}

\subsection{Desain Produk}

Adapun perancangan desain produk aplikasi sistem pakar untuk mendiagnosa penyakit yang diakibatkan terkena gigitan nyamuk akan akan digambarkan dengan menggunakan usecase 
diagram. Untuk perancangan desain produk berupa usecase diagram akan ditunjukkan pada gambar 2 berikut ini.

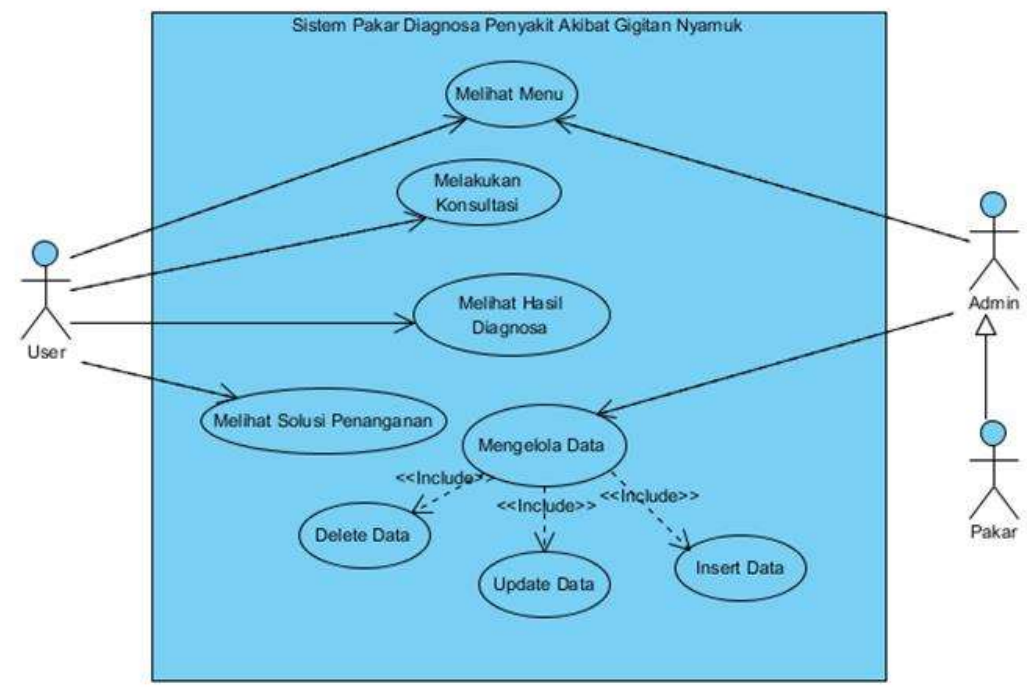

Gambar 2. Perancangan Usecase Diagram

Dari gambar diatas, terdapat tiga aktor yang dapat menjalankan aplikasi sistem pakar diagnosa penyakit akibat gigitan nyamuk, yaitu user, admin dan seorang pakar. Untuk aktor user dapat melakukan proses melihat menu yang ada pada aplikasi, kemudian user dapat melakukan konsultasi yang didalamya terdapat pertanyaan. Setelah menjawab pertanyaan, user dapat melihat hasil diagnosa dan didalamnya terdapat solusi penanganan yang diberikan oleh sistem kepada user sebagai pertolongan pertama.

Aktor berikutnya adalah admin dan seorang pakar. Kedua aktor ini saling berkaitan dikarenakan admin dapat mengelola proses data gejala penyakit, mengelola proses data jenis nyamuk dan mengelola proses data solusi yang diperoleh dari seorang pakar kesehatan, yaitu dokter.

\subsection{Validasi Produk}

Validasi produk adalah suatu proses kegiatan yang bertujuan untuk menilai rancangan suatu produk yang sudah dibuat apakah sesuai dengan kriteria yang sudah ditetapkan dari pakar dokter umum atau tidak.

\subsection{Revisi Produk}

Setelah proses validasi selesai, maka akan dapat diketahui kelemahannya dan pakar ahli tersebut akan menemukan beberapa konten yang perlu diubah, direvisi, atau dibuang, setelah itu baru diperbaiki.

\subsection{Pembuatan Produk}

Dalam proses pembuatan produk aplikasi sistem pakar, perlu dirancang struktur desain tampilan atau user interface terlebih dahulu. Gunanya dibuat struktur perancangan desain user interface terlebih dahulu yaitu untuk mempermudah user untuk menggunakan aplikasi sistem pakar ini untuk mendiagnosa penyakit yang diakibatkan oleh gigitan nyamuk. Untuk struktur user interface, dapat dilihat pada gambar 3 berikut ini. 


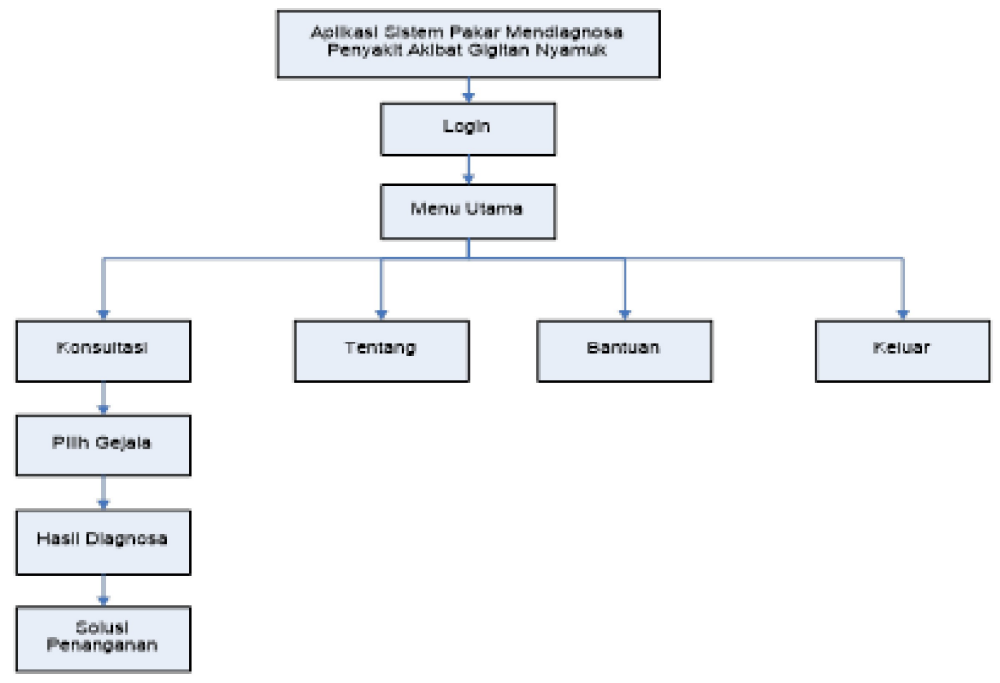

Gambar 3. Struktur Perancangan Desain User Interface

\subsection{Uji Coba Produk}

Setelah desain telah selesai dibuat, maka proses selanjutnya dilakukan proses skenario uji coba produk yang dilakukan dengan cara membandingkan antara hasil penyakit yang diolah oleh sistem dengan hasil pendapat dari pakar dokter umum.

\subsection{Produk}

Hasil akhir dari penelitian ini adalah sebuah produk berupa software aplikasi sistem pakar untuk mendiagnosa penyakit akibat terkena gigitan nyamuk berbasis andorid.

\section{HASIL DAN PEMBAHASAN}

\subsection{Metode Certainty Factor}

Pada tahun 1975, metode certainty factor merupakan sebuah metode yang ditemukan oleh Shortliffe dan Buchanan.[10] Metode certainty factor digunakan untuk mengakomodasi ketidakpastian pemikiran (inexact reasoning) dari seorang pakar. Pakar adalah orang yang ahli dalam bidang tertentu, yang mempunyai pengalaman dan pengetahuan dalam memecahkan suatu masalah. [11] Seorang pakar, semisal dalam penelitian ini dokter, sering menganalisa informasi dengan ungkapan "mungkin", "kemungkinan besar" atau "hampir pasti", sehingga dengan adanya metode certainty factor ini dapat mengambarkan tingkat keyakinan seorang pakar dalam pengmbilan keputusan terhadap masalah yang sedang dihadapi. [12,13] Perhitungan dari metode certainty factor ditunjukkan pada persamaan berikut ini.

$$
\mathrm{CF}[\mathrm{h}, \mathrm{e}]_{1}=\mathrm{CF}[\mathrm{h}]_{1} * \mathrm{CF}[\mathrm{e}]_{1}
$$

Yang mana :

$\mathrm{CF}[\mathrm{h}, \mathrm{e}]=$ Certainty Factor atau faktor kepastian dalam hipotesis h yang dipengaruhi oleh gejala $\mathrm{e}$

$\mathrm{CF}[\mathrm{h}]=$ Certainty Factor dari pakar terhadap hipotesis $\mathrm{h}$.

$\mathrm{CF}[\mathrm{e}]=$ Certainty Factor dari user terhadap gejala $\mathrm{e}$

Perhitungan selanjutnya adalah dikombinasikan dua atau lebih rule dengan evidence berbeda tetapi dalam hipotesis yang sama dengan persamaan sebagai berikut :

$$
\mathrm{CF}_{\text {combine }}\left[\mathrm{CF}_{1}, \mathrm{CF}_{2}\right]=\mathrm{CF}_{1}+\left(\mathrm{CF}_{2} *\left[1-\mathrm{CF}_{1}\right]\right)
$$
berikut :

Perhitungan terakhir adalah untuk menghitung persentase digunakan persamaan sebagai

$$
\mathrm{CF}_{\text {persentase }}=\mathrm{CF}_{\text {combine }} * 100 \%
$$


Penyelesaian permasalahan dalam mendeteksi penyakit yang diakibatkan oleh gigitan nyamuk dengan metode certainty factor adalah sebagai berikut:

a. Pertama, diketahui gejala yang dialami oleh stakeholder meliputi : Pendarahan diantaranya mimisan, muntah darah dan BAB berdarah (G01); demam tinggi secara mendadak kemudian demam turun lalu demam naik lagi (G02); nafsu makan menurun (G03).

b. Kedua, menentukan nilai CF[h] dari dokter sesuai dengan gejala yang dialami oleh stakeholder.

Tabel 2. Nilai CF[h] Dari Dokter

\begin{tabular}{|c|c|c|}
\hline No & Kode Gejala & Nilai CF[h] \\
\hline 1 & G01 & 0,8 \\
\hline 2 & G02 & 0,4 \\
\hline 3 & G03 & 0,3 \\
\hline
\end{tabular}

c. Ketiga, pemberian nilai bobot dari user.

Tabel 3. Pemberian Nilai Bobot User

\begin{tabular}{|c|c|c|}
\hline No & Keterangan & Nilai Bobot User \\
\hline 1 & Tidak Tahu & 0 \\
\hline 2 & Sedikit Yakin & 0,2 \\
\hline 3 & Cukup Yakin & 0,5 \\
\hline 4 & Yakin & 0,8 \\
\hline 5 & Sangat Yakin & 1 \\
\hline
\end{tabular}

d. Keempat, menentukan nilai bobot user atau $\mathrm{CF}[\mathrm{e}]$ sesuai dengan gejala yang dialami.

Tabel 4. Nilai CF[e] Dari User

\begin{tabular}{|c|c|c|c|}
\hline No & Kode Gejala & Keterangan & Nilai CF[e] \\
\hline 1 & G01 & Yakin & 0,8 \\
\hline 2 & G02 & Yakin & 0,8 \\
\hline 3 & G03 & Cukup Yakin & 0,5 \\
\hline
\end{tabular}

e. Kelima, menghitung nilai $\mathrm{CF}$ dengan mengalikan $\mathrm{CF}[\mathrm{h}]$ dengan $\mathrm{CF}[\mathrm{e}]$.

$$
\begin{aligned}
& \mathrm{CF}[\mathrm{h}, \mathrm{e}]_{1}=\mathrm{CF}[\mathrm{h}]_{1} * \mathrm{CF}[\mathrm{e}]_{1}=0,8 * 0,8=0,64 \\
& \mathrm{CF}[\mathrm{h}, \mathrm{e}]_{2}=\mathrm{CF}[\mathrm{h}]_{2} * \mathrm{CF}[\mathrm{e}]_{2}=0,4 * 0,8=0,32 \\
& \mathrm{CF}[\mathrm{h}, \mathrm{e}]_{3}=\mathrm{CF}[\mathrm{h}]_{3} * \mathrm{CF}[\mathrm{e}]_{3}=0,3 * 0,5=0,15
\end{aligned}
$$

f. Keenam, menghitung $\mathrm{CF}$ Kombinasi.

$$
\begin{aligned}
\mathrm{CF}_{\text {combine } 1}\left[\mathrm{CF}_{1}, \mathrm{CF}_{2}\right]=\mathrm{CF}_{1} & +\left(\mathrm{CF}_{2} *\left[1-\mathrm{CF}_{1}\right]\right)=0,64+(0,32 *[1-0,64])=0,76_{\text {combine } 1} \\
\mathrm{CF}_{\text {combine } 2}\left[\mathrm{CF}_{\text {combine1 } \left.1, \mathrm{CF}_{2}\right]}=\right. & \mathrm{CF}_{\text {combine } 1}+\left(\mathrm{CF}_{2} *\left[1-\mathrm{CF}_{\text {combine } 1}\right]\right)=0,76+(0,32 *[1-0,76]) \\
& =0,84_{\text {combine2 }} \\
\mathrm{CF}_{\text {combine3 } 3}\left[\mathrm{CF}_{\text {combine2 } 2,} \mathrm{CF}_{3}\right] & =\mathrm{CF}_{\text {combine } 2}+\left(\mathrm{CF}_{3} *\left[1-\mathrm{CF}_{\text {combine } 2}\right]\right)=0,84+(0,15 *[1-0,84]) \\
& =0,864_{\text {combine3 }}
\end{aligned}
$$

g. Ketujuh, menghitung persentase nilai CF kombinasi

$$
\mathrm{CF}_{\text {persentase }}=\mathrm{CF}_{\text {combine3 }} * 100 \%=\mathbf{8 6 , 4} \%
$$

Setelah dihitung dengan menggunakan metode certainty factor, hasil dari penelitian ini dapat dilihat pada tabel 2 berikut ini.

Tabel 5. Hasil Perhitungan Metode Certainty Factor

\begin{tabular}{|c|l|c|}
\hline No & \multicolumn{1}{|c|}{ Gejala Yang Dialami } & $\begin{array}{c}\text { Hasil } \\
\text { Perhitungan } \\
\text { CF }\end{array}$ \\
\hline 1 & $\begin{array}{l}\text { Pendarahan diantaranya mimisan, muntah darah dan BAB berdarah; } \\
\text { demam tinggi secara mendadak kemudian demam turun lalu demam } \\
\text { naik lagi; nafsu makan menurun. }\end{array}$ & $86,4 \%$ \\
\hline
\end{tabular}




\begin{tabular}{|c|l|c|}
\hline 2 & $\begin{array}{l}\text { Pusing diikuti dengan rasa lemah, letih dan lesu; tubuh terasa } \\
\text { dingin; muncul bintik merah pada kulit }\end{array}$ & $82,3 \%$ \\
\hline 3 & $\begin{array}{l}\text { Demam tinggi secara mendadak kemudian demam turun lalu } \\
\text { demam naik lagi; tubuh terasa dingin; muncul bintik merah pada } \\
\text { kulit }\end{array}$ & $99,4 \%$ \\
\hline 4 & $\begin{array}{l}\text { Nafsu makan menurun; pusing diikuti dengan rasa lemah, letih dan } \\
\text { lesu; tubuh terasa dingin }\end{array}$ & $87,5 \%$ \\
\hline 5 & $\begin{array}{l}\text { Demam tinggi secara mendadak kemudian demam turun lalu } \\
\text { demam naik lagi; nafsu makan menurun; mual disertai dengan } \\
\text { muntah. }\end{array}$ & $92,3 \%$ \\
\hline 6 & $\begin{array}{l}\text { Demam tinggi secara mendadak kemudian demam turun lalu } \\
\text { demam naik lagi; nafsu makan menurun; pusing diikuti dengan rasa } \\
\text { lemah. }\end{array}$ & $80,5 \%$ \\
\hline 7 & $\begin{array}{l}\text { Pendarahan diantaranya mimisan, muntah darah dan BAB berdarah; } \\
\text { demam tinggi secara mendadak kemudian demam turun lalu demam } \\
\text { naik lagi; nafsu makan menurun dan bintik merah pada kulit. }\end{array}$ & $86,5 \%$ \\
\hline 8 & $\begin{array}{l}\text { Mual disertai dengan muntah; nyeri pada badan dan susah buang air } \\
\text { besar }\end{array}$ & $85,4 \%$ \\
\hline 9 & Nyeri pada badan dan susah buang air besar & $81,2 \%$ \\
\hline 10 & $\begin{array}{l}\text { Pusing diikuti dengan rasa lemah, letih dan lesu; nyeri pada badan; } \\
\text { susah buang air besar }\end{array}$ & $98,4 \%$ \\
\hline
\end{tabular}

\subsection{Metode Nä̈ve Bayes}

Sekitar tahun 1950, metode nä̈ve bayes ini ditemukan oleh seseorang ilmuan yang bernama Thomas Bayes.[12] Metode naïve bayes adalah teknik prediksi berbasis probabilitas yang berdasar pada sebuah kondisi probabilitas yang memperhitungkan probabilitas suatu kejadian (hipotesis) yang bergantung pada bukti dari kejadian sebelumnya.[13,14] Jadi, pada intinya metode naïve bayes digunakan untuk menghitung sekaligus memprediksi probabilitas dari keanggotaan suatu class. Perhitungan dari metode naïve bayes ditunjukkan pada persamaan berikut ini.

$$
P(H \mid X)=\frac{P(X \mid H) P(H)}{P(X)}
$$

Yang mana :

$$
\begin{array}{ll}
\mathrm{X} & =\text { adalah data yang belum diketahui } \\
\mathrm{H} & =\text { hipotesis data } \mathrm{X} \text { merupakan suatu class spesifik } \\
\mathrm{P}(\mathrm{H} \mid \mathrm{X}) & =\text { Probabilitas hipotesis } \mathrm{H} \text { berdasarkan kondisi } \mathrm{X} \\
\mathrm{P}(\mathrm{H}) & =\text { Probabilitas Hipotesis } \mathrm{H} \\
\mathrm{P}(\mathrm{X} \mid \mathrm{H}) & =\text { Probabilitas } \mathrm{X} \text { berdasar kondisi pada Hipotesis } \mathrm{H} \\
\mathrm{P}(\mathrm{X}) & =\text { Probabilitas dari } \mathrm{X}
\end{array}
$$

Penyelesaian permasalahan dalam mendeteksi penyakit yang diakibatkan oleh gigitan nyamuk dengan metode nä̈ve bayes adalah sebagai berikut:

a. Pertama, diketahui gejala yang dialami oleh stakeholder meliputi : Pendarahan diantaranya mimisan, muntah darah dan BAB berdarah (G01); demam tinggi secara mendadak kemudian demam turun lalu demam naik lagi (G02); nafsu makan menurun (G03).

b. Kedua, membaca data gejala dan jenis nyamuk. Dapat dilihat pada tabel 1.

c. Ketiga, menghitung $\mathrm{P}(\mathrm{H})$ berdasarkan probabilitas prediksi jenis gigitan nyamuk.

$$
\begin{aligned}
& P(N 01)=6 / 9=0,67 \\
& P(N 02)=3 / 9=0,33 \\
& P(N 03)=3 / 9=0,33
\end{aligned}
$$

d. Keempat, menghitung probabilitas kelas $\mathrm{P}(\mathrm{X} \mid \mathrm{H})$.

$$
\begin{aligned}
& P(\text { N01 } \mid \text { Gejala })=1 / 3=0,33 \\
& P(\text { N02 } \mid \text { Gejala })=2 / 3=0,67 \\
& P(\text { N03 } \mid \text { Gejala })=2 / 3=0,67 \\
& P(X \mid \text { Jenis Nyamuk })=0,33 * 0,67 * 0,67=0,15
\end{aligned}
$$


e. Kelima, menghitung probabilitas akhir $\mathrm{P}(\mathrm{H} \mid \mathrm{X})$ dengan cara mengkalikan $\mathrm{P}(\mathrm{H})$ dengan $\mathrm{P}(\mathrm{X} \mid \mathrm{H})$

$\mathrm{P}(\mathrm{N} 01) \mathrm{P}(\mathrm{X} \mid$ Jenis Nyamuk $)=0,67 * 0,15=\mathbf{0 , 1 0 0 5}$

$\mathrm{P}(\mathrm{N} 02) \mathrm{P}(\mathrm{X} \mid$ Jenis Nyamuk $)=0,33 * 0,15=0,0495$

$\mathrm{P}(\mathrm{N} 03) \mathrm{P}(\mathrm{X} \mid$ Jenis Nyamuk $)=0,33 * 0,15=0,0495$

Dikarenakan nilai 0,1005 paling besar, maka gejala yang telah dialami oleh stakeholder diklasifikasikan terkena gigitan nyamuk jenis demam berdarah.

Setelah dihitung dengan menggunakan metode naïve bayes, hasil dari penelitian ini dapat dilihat pada tabel 3 berikut ini.

Tabel 3. Hasil Klasifikasi Metode Nä̈ve Bayes

\begin{tabular}{|c|c|c|}
\hline No & Gejala Yang Dialami & $\begin{array}{l}\text { Hasil Klasifikasi } \\
\text { Naïve Bayes }\end{array}$ \\
\hline 1 & $\begin{array}{l}\text { Pendarahan diantaranya mimisan, muntah darah dan } \mathrm{BAB} \\
\text { berdarah; demam tinggi secara mendadak kemudian demam turun } \\
\text { lalu demam naik lagi; nafsu makan menurun }\end{array}$ & Demam Berdarah \\
\hline 2 & $\begin{array}{l}\text { Pusing diikuti dengan rasa lemah, letih dan lesu; tubuh terasa } \\
\text { dingin; muncul bintik merah pada kulit }\end{array}$ & Demam Berdarah \\
\hline 3 & $\begin{array}{l}\text { Demam tinggi secara mendadak kemudian demam turun lalu } \\
\text { demam naik lagi; tubuh terasa dingin; muncul bintik merah pada } \\
\text { kulit }\end{array}$ & Demam Berdarah \\
\hline 4 & $\begin{array}{l}\text { Nafsu makan menurun; pusing diikuti dengan rasa lemah, letih dan } \\
\text { lesu; tubuh terasa dingin }\end{array}$ & Demam Berdarah \\
\hline 5 & $\begin{array}{l}\text { Demam tinggi secara mendadak kemudian demam turun lalu } \\
\text { demam naik lagi; nafsu makan menurun; mual disertai dengan } \\
\text { muntah. }\end{array}$ & Malaria \\
\hline 6 & $\begin{array}{l}\text { Demam tinggi secara mendadak kemudian demam turun lalu } \\
\text { demam naik lagi; nafsu makan menurun; pusing diikuti dengan rasa } \\
\text { lemah. }\end{array}$ & Demam Berdarah \\
\hline 7 & $\begin{array}{l}\text { Pendarahan diantaranya mimisan, muntah darah dan } \mathrm{BAB} \\
\text { berdarah; demam tinggi secara mendadak kemudian demam turun } \\
\text { lalu demam naik lagi; nafsu makan menurun dan bintik merah pada } \\
\text { kulit. }\end{array}$ & Demam Berdarah \\
\hline 8 & $\begin{array}{l}\text { Mual disertai dengan muntah; nyeri pada badan dan susah buang } \\
\text { air besar }\end{array}$ & Malaria \\
\hline 9 & Nyeri pada badan dan susah buang air besar & Chikungunya \\
\hline 10 & $\begin{array}{l}\text { Pusing diikuti dengan rasa lemah, letih dan lesu; nyeri pada badan; } \\
\text { susah buang air besar }\end{array}$ & Chikungunya \\
\hline
\end{tabular}

3.3. Implementasi Aplikasi Sistem Pakar Berbasis Android

Pada bagian implementasi ini akan memberikan gambaran terhadap hasil pengujian

terhadap fitur-fitur yang tersedia pada aplikasi sistem pakar berbasis android yang telah

disesuaikan dengan perancangan desain yang telah dibuat.

\subsubsection{Halaman Menu}

Pada halaman menu ini terdapat berbagai menu yang nantinya dapat digunakan oleh stakeholder, diantaranya menu konsultasi, menu tentang dan menu bantuan. Untuk tampilan halaman menu dari aplikasi ini dapat dilihat pada gambar 4 berikut ini. 


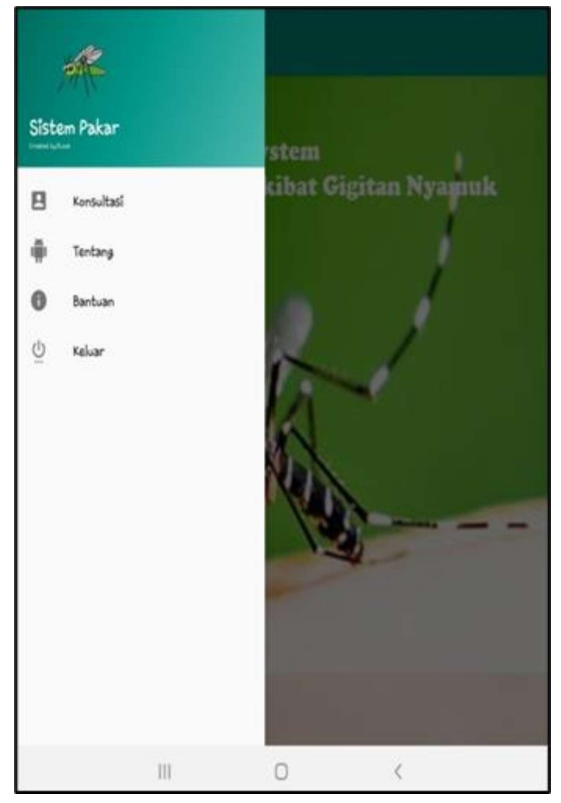

Gambar 4. Halaman Menu Aplikasi Sistem Pakar

3.3.2. Halaman Konsultasi

Pada halaman menu konsultasi ini terdapat bagian dimana stakeholder memilih gejala yang telah dialami oleh tubuh setalah digigit oleh nyamuk. Untuk tampilan halaman menu konsultasi dari aplikasi ini dapat dilihat pada gambar 5 berikut ini.

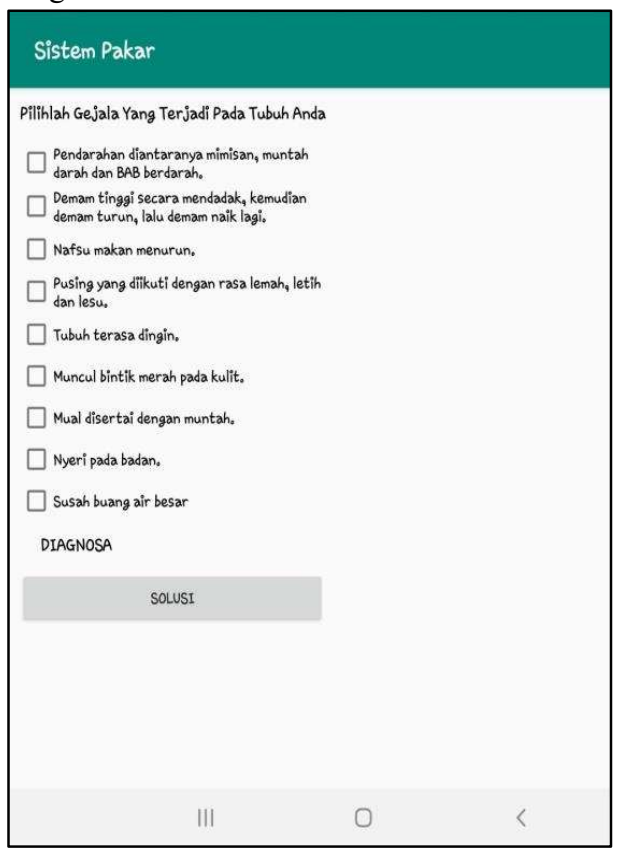

Gambar 5. Halaman Konsultasi Aplikasi Sistem Pakar

\subsubsection{Halaman Diagnosa}

Setelah stakeholder memilih gejala yang dialami, maka sistem akan menampilkan penyakit yang diderita oleh stakeholder disertai solusinya. Untuk tampilan halaman menu diagnosa dapat dilihat pada gambar 6 berikut ini. 


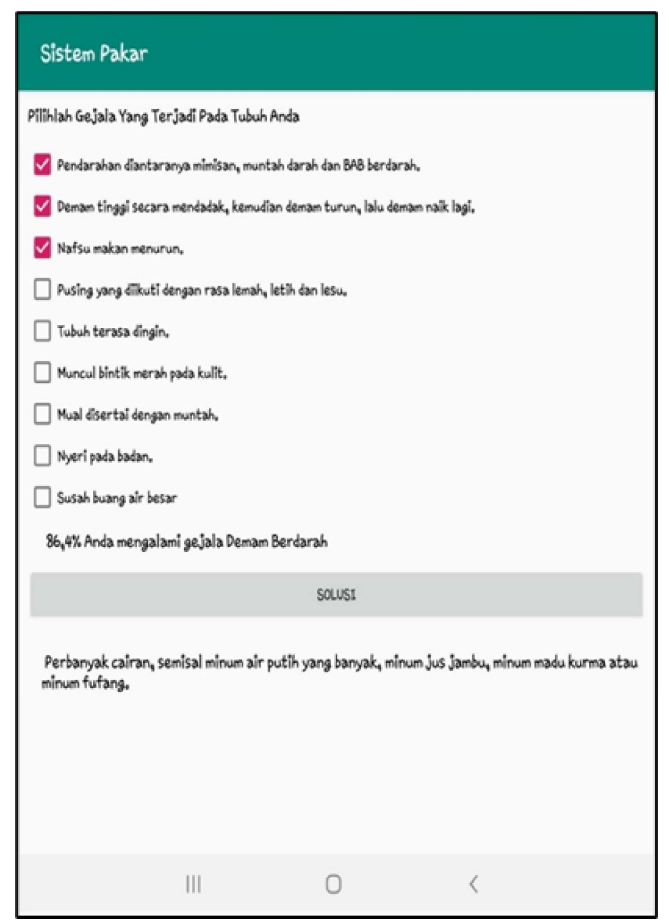

Gambar 6. Halaman Diagnosa Aplikasi Sistem Pakar

\subsection{Skenario Uji Coba}

Untuk skenario uji coba hasil aplikasi diagnosa akibat gigitan nyamuk ditunjukkan pada tabel 4 berikut ini.

Tabel 2. Hasil Uji Coba Sistem Aplikasi Sistem Pakar

\begin{tabular}{|c|c|c|c|c|}
\hline No & Gejala Yang Dialami & $\begin{array}{l}\text { Diagnosa } \\
\text { Hasil } \\
\text { Aplikasi }\end{array}$ & $\begin{array}{l}\text { Diagnosa } \\
\text { Dari Pakar }\end{array}$ & Akurasi \\
\hline 1 & $\begin{array}{l}\text { Pendarahan diantaranya mimisan, muntah } \\
\text { darah dan BAB berdarah; demam tinggi } \\
\text { secara mendadak kemudian demam turun lalu } \\
\text { demam naik lagi; nafsu makan menurun }\end{array}$ & $\begin{array}{l}\text { Demam } \\
\text { Berdarah }\end{array}$ & $\begin{array}{l}\text { Demam } \\
\text { Berdarah }\end{array}$ & Tepat \\
\hline 2 & $\begin{array}{l}\text { Pusing diikuti dengan rasa lemah, letih dan } \\
\text { lesu; tubuh terasa dingin; muncul bintik } \\
\text { merah pada kulit }\end{array}$ & $\begin{array}{l}\text { Demam } \\
\text { Berdarah }\end{array}$ & $\begin{array}{c}\text { Demam } \\
\text { Berdarah }\end{array}$ & Tepat \\
\hline 3 & $\begin{array}{l}\text { Demam tinggi secara mendadak kemudian } \\
\text { demam turun lalu demam naik lagi; tubuh } \\
\text { terasa dingin; muncul bintik merah pada kulit }\end{array}$ & $\begin{array}{l}\text { Demam } \\
\text { Berdarah }\end{array}$ & $\begin{array}{c}\text { Demam } \\
\text { Berdarah }\end{array}$ & Tepat \\
\hline 4 & $\begin{array}{l}\text { Nafsu makan menurun; pusing diikuti dengan } \\
\text { rasa lemah, letih dan lesu; tubuh terasa dingin }\end{array}$ & $\begin{array}{l}\text { Demam } \\
\text { Berdarah }\end{array}$ & $\begin{array}{l}\text { Demam } \\
\text { Berdarah }\end{array}$ & Tepat \\
\hline 5 & $\begin{array}{l}\text { Demam tinggi secara mendadak kemudian } \\
\text { demam turun lalu demam naik lagi; nafsu } \\
\text { makan menurun; mual disertai dengan } \\
\text { muntah. }\end{array}$ & Malaria & Malaria & Tepat \\
\hline 6 & $\begin{array}{l}\text { Demam tinggi secara mendadak kemudian } \\
\text { demam turun lalu demam naik lagi; nafsu } \\
\text { makan menurun; pusing diikuti dengan rasa } \\
\text { lemah. }\end{array}$ & $\begin{array}{l}\text { Demam } \\
\text { Berdarah }\end{array}$ & $\begin{array}{l}\text { Demam } \\
\text { Berdarah }\end{array}$ & Tepat \\
\hline 7 & $\begin{array}{l}\text { Pendarahan diantaranya mimisan, muntah } \\
\text { darah dan BAB berdarah; demam tinggi } \\
\text { secara mendadak kemudian demam turun lalu }\end{array}$ & $\begin{array}{l}\text { Demam } \\
\text { Berdarah }\end{array}$ & $\begin{array}{c}\text { Demam } \\
\text { Berdarah }\end{array}$ & Tepat \\
\hline
\end{tabular}




\begin{tabular}{|c|c|c|c|c|}
\hline & $\begin{array}{l}\text { demam naik lagi; nafsu makan menurun dan } \\
\text { bintik merah pada kulit. }\end{array}$ & & & \\
\hline 8 & $\begin{array}{l}\text { Mual disertai dengan muntah; nyeri pada } \\
\text { badan dan susah buang air besar }\end{array}$ & Malaria & $\begin{array}{c}\text { Chikungun } \\
\text { ya }\end{array}$ & Meleset \\
\hline 9 & Nyeri pada badan dan susah buang air besar & $\begin{array}{c}\text { Chikungun } \\
\text { ya }\end{array}$ & $\begin{array}{c}\text { Chikungun } \\
\text { ya }\end{array}$ & Tepat \\
\hline 10 & $\begin{array}{l}\text { Pusing diikuti dengan rasa lemah, letih dan } \\
\text { lesu; nyeri pada badan; susah buang air besar }\end{array}$ & $\begin{array}{c}\text { Chikungun } \\
\text { ya }\end{array}$ & $\begin{array}{c}\text { Chikungun } \\
\text { ya }\end{array}$ & Tepat \\
\hline
\end{tabular}

Dari 10 skenario pengujian diatas berdasarkan gejala yang dialami oleh stakeholder, perbandingan antara diagnosa hasil perhitungan aplikasi dengan diagnosa dari pakar, menghasilkan nilai yang tepat 9 dan yang meleset 1 . Jadi, akurasi aplikasi sistem pakar diagnosa penyakit akibat gigitan nyamuk dengan metode certainty factor dan naïve bayes yang sudah dibuat sebesar $90 \%$.

\section{SIMPULAN}

Berdasarkan pembahasan yang telah diuraikan di atas, maka dapat diambil beberapa kesimpulan antara lain sebagai berikut:

1. Aplikasi sistem pakar yang sudah dirancang ini, mampu memberikan informasi kepada stakeholder dalam mendiagnosa penyakit yang disebabkan oleh gigitan nyamuk berdasarkan gejala yang dialami beserta solusinya.

2. Penerapan metode certainty factor dalam aplikasi sistem pakar mampu memberikan hasil perhitungan persentase dalam mendeteksi penyakit yang disebabkan oleh gigitan nyamuk.

3. Penerapan metode naïve bayes dalam aplikasi sistem pakar mampu mendeteksi jenis nyamuk.

4. Hasil akurasi aplikasi sistem pakar untuk mendiagnosa penyakit yang disebebkan oleh gigitan nyamuk dengan menggunakan metode certainty factor dan naïve bayes ini adalah sebesar $90 \%$.

\section{SARAN}

Untuk perbaikan dan pengembangan dalam penelitian ini dimasa yang akan datang, disarankan untuk :

1. Bisa ditambahkan maupun dibandingkan dengan metode lainnya selain certainty factor dan nä̈ve bayes, sehingga dapat diketahui hasil keakurasiannya terhadap gejala yang timbul.

2. Bisa ditambahkan perbandingan antara gejala gigitan nyamuk dengan tipes, cacar air ataupun demam biasa, dikarenakan gejalanya hampir mirip.

\section{DAFTAR PUSTAKA}

[1] R.E.M. Sari, " Penerapan Metode Certainty Factor Untuk Diagnosis Penyakit Pada Anak ", Jurnal Ilmiah NERO, Vol 5. No 1

[2] P. Astuti , " Hubungan Kondisi Lingkungan Fisik Terhadap Tingkat Kepadatan Larva Aedes sp Di Sekolah Dasar Wilayah Kecamatan Kasihan Bantul DI Yogyakarta ", Jurnal Ilmu Kesehatan Masyarakat. Vol 9. No 3. Pp 216-225.

[3] N. Nur and S. Endang," Sistem Pakar Untuk Mendiagnosa Penyakit Yang Disebabkan Nyamuk Dengan Metode Forward Chaining”, Jurnal Jitika, Vol 6. No 2, pp 20-25, 2012.

[4] J, Nanda ,and T, Roden, “ Sistem Pakar Diagnosa Penyakit Alergi Pada Anak Berbasis Web Dengan Metode Forward Chaining Di Kota Batam”,Jurnal Edik Informatika, Vol 3. No 2. 2017

[5] K. Kusrini. ,"Aplikasi Sistem Pakar", Andi, Yogyakarta,2008

[6] S. Setyaputri, F. Fadlil,A. Abdul dan S.Sunardi," Analisis Metode Certainty Factor Pada Sistem Pakar Diagnosa Penyakit THT”,Jurnal Teknik Elektro. Vol 10. No 1. Pp. 30-35. 2018

[7] P. Buani, and D. Cahya,"Prediksi Penyakit Hepatitis Menggunakan Agoritma Naïve Bayes Dengan Seleksi Fitur Algoritma Genetika", Jurnal Evolusi, Vol 6. No 2, 2018.

[8] P, Sigit,"Metode Penelitian dan Pengembangan (Pengenalan Untuk Mengembangkan Produk Pembelajaran Bahasa Arab).”,Jurnal Literasi, Vol 4. No 1. pp19-32, 2013.

[9] S. Sugiyono, “ Metode Penelitian Kuantitatif Kualitatif dan R\&D”,Bandung, Alfabeta,2010

[10] M. Arifin, S. Slamin,and W.E.Y. Retnani ," Penerapan Metode Certainty Factor Untuk Sistem Pakar Diagnosis Hama dan Penyakit Pada Tanaman Tembakau”, Jurnal Sainstek, Vol 5. No 1. ppl 21-28.

[11] H.T. Sihotang, "Sistem Pakar Mendiagnosa Penyakit Kolesterol Pada Remaja Dengan metode Certainty Factor Berbasis Web", Jurnal Mantik Penusa, Vol 15. No 1, 2014. 
[12] A.H. Aji , M.T. Furqon, A.W. Widodo," Sistem Pakar Diagnosa Penyakit Ibu Hamil Menggunakan Metode Certainty Factor",Jurnal Pengembangan Teknologi Informasi dan Ilmu Komputer, Vol 2. No 5. 2018

[13] N.A. Hasibuan, A. Sunandar, S. Alas, and S. Suginam," Sistem Pakar Mendiagnosa Penyakit Kaki Gajah Menggunakan Metode Certainty Factor”, Jurnal Jurasik. Vol 2. No1.2017

[14] F. Handayani, and F.S. Pribadi, F.S,'Implementasi Algoritma Naïve Bayes Classifier Dalam Pengklasifikasian Teks Otomatis Pengaduan dan Pelaporan Masyarakat Melalui Layanan Call Center 110”, . Jurnal Teknik Elektro, Vol 7. No 1, 2015

[15] N.D. Prayoga,N. Hidayat, and R.K, Dewi,"Sistem Diagnosis Penyakit Hati Menggunakan Metode Naïve Bayes", Jurnal Pengembangan Teknologi Informasi dan Teknik Komputer, Vol 2. No 8, 2018

[16] Y.K. Sari," Implementasi Klasifikasi Data Mining Untuk Memprediksi Kelulusan Mahasiswa Menggunakan Algoritma Naïve Bayes," Generation Journal. Vol 1. No 2. pp 96-103.2017 